\title{
Virginie Minet-Mahy, Lyrisme de plainte et lyrisme de joie dans trois grands mystères français du $\mathrm{XV}^{\mathrm{e}}$ siècle
}

\author{
Maria Colombo Timelli
}

\section{(2) OpenEdition}

1 Journals

\section{Édition électronique}

URL : http://journals.openedition.org/studifrancesi/34417

DOI : $10.4000 /$ studifrancesi.34417

ISSN : 2421-5856

Éditeur

Rosenberg \& Sellier

\section{Édition imprimée}

Date de publication : 1 novembre 2005

Pagination : 394

ISSN : 0039-2944

\section{Référence électronique}

Maria Colombo Timelli, « Virginie Minet-Mahy, Lyrisme de plainte et lyrisme de joie dans trois grands mystères français du XVe siècle », Studi Francesi [En ligne], 146 (XLIX | II) | 2005, mis en ligne le 30 novembre 2015, consulté le 20 avril 2021. URL : http://journals.openedition.org/studifrancesi/34417 ; DOI : https://doi.org/10.4000/studifrancesi.34417

Ce document a été généré automatiquement le 20 avril 2021.

\section{(c)}

Studi Francesi è distribuita con Licenza Creative Commons Attribuzione - Non commerciale - Non opere derivate 4.0 Internazionale. 


\title{
Virginie Minet-Mahy, Lyrisme de plainte et lyrisme de joie dans trois grands mystères français du $X V^{\mathrm{e}}$ siècle
}

\author{
Maria Colombo Timelli
}

\section{RÉFÉRENCE}

VIRGINIE MINET-MAHY, Lyrisme de plainte et lyrisme de joie dans trois grands mystères français $d u X^{e}$ siècle, «Fifteenth-Century Studies», 29, 2004, pp. 133-59.

1 À partir d'un corpus réduit mais significatif de textes dramatiques, Virginie MinetMahy observe l'insertion et le fonctionnement des douzains sur rimes en miroir aabaab bbabba et leur rapport avec l'expression de la plainte et de la joie. Que ce soit dans le Mystère de la Passion d'Arnoul Gréban, le Mystère de la Résurrection (Angers, 1456), ou encore le Mystère de la Passion de Jean Michel, représenté dans la même ville trente ans plus tard, on reconnaît l'emploi de formes lyriques complexes aux endroits clés des textes: les prologues, les plaintes devant la Passion, notamment celles de la Vierge et de Marie-Madeleine, les louanges devant l'Annonciation, la Nativité, la Résurrection. Qui plus est, ce travail poétique coïncide avec une intensification du message théologique qui ne pourrait être le fruit du hasard. Si la question reste ouverte quant à la perception des variations métriques de la part du public des mystères, le raffinement de la versification y joue sans aucun doute un rôle non secondaire. 